DOI: https://10.15407/kvt198.04.026

UDC 004.942: 681.513.8

TOKOVA O.V.,

Junior Researcher of the Department of Information

Technologies for Inductive Modeling

e-mail: len327@ukr.net

SAVCHENKO Ye.A., PhD (Engineering),

Senior Researcher of the Department of Information

Technologies for Inductive Modeling

e-mail: savchenko_e@meta.ua

STEPASHKO V.S., DSc (Engineering), Professor,

Head of the Department of Information

Technologies for Inductive Modeling

e-mail: stepashko@irtc.org.ua

International Research and Training Center for Information Technologies

and Systems of the National Academy of Sciences of Ukraine

and Ministry of Education and Science of Ukraine,

40, Acad. Glushkov av., Kyiv, 03187, Ukraine

\title{
CONSTRUCTION OF A COMPUTER TECHNOLOGY FOR INFORMATION SUPPORT OF DECISIONS IN THE FOUNDRY PRODUCTION PROCESS
}

Introduction. To ensure the high-quality manufacture of foundry products, advanced computer technologies are required which would contain not only a database of metals and alloys but also information on defect formation processes and methods for producing castings of a given quality. Software development requires detailed analysis not only of existing advanced technologies, but also the needs of the customer, compliance with all stages of the technological process, determination of the production profile.

The purpose of the paper is to analyze existing approaches and tools used in the foundry support industry to develop a computer technology containing a database of Ukrainian standards and specifications and providing guidance on the tasks involved in the casting process. To construct such technology for supporting the foundry making in the casting process, it is necessary to identify the advantages and disadvantages of existing facilities, assess the feasibility of using these tools in the domestic production and formulate requirements for computer technology developed in accordance with specifics of the Ukrainian foundries and oriented to work with the domestic base of metals and alloys.

Results. The analysis of modern software for computer modeling of processes in the field of formation of metals and alloys is carried out. It is planned to use the results of the analysis when creating a computer technology for modeling thermal processes in the field of foundry production focused on the Ukrainian industry to simplify the casting process. This will increase the production volume and reduce the appearance of defects in casting products during the technological process to make them more competitive. The block diagram of the computer technology of information support for decision-making in the foundry process is given. The main blocks of this system and the tasks they will solve are described. 
Conclusions. An analysis of modern software for computer simulation of processes in the field of metal molding and the methods which are the basis of software products is executed. The results of the analysis are used when creating the computer technology of simulation of the thermal processes in the field of foundry, which will be oriented on Ukrainian industries, simplify the process of the casting obtaining. This will result in an increase of the production volume and reduce the appearance of defects in casting products during technological process to make them more competitive.

Keywords: casting, foundry production, computer technology, information support of decisions, group method of data handling (GMDH).

\section{INTRODUCTION}

Casting is a process in which various transformations are involved and it carries risk of failures producing defects in casting which ultimately leads to rejection of the casting product [1].

In order to provide fast and qualitative production of casting products, advanced computer technologies are needed that would contain not only the database of metals and their alloys, but also information on the processes of defect formation, methods of obtaining castings of the given quality for a particular production, conditions and factors that influence the structure of casting during thermal treatments.

The use of information technologies at the Ukrainian foundries means making adjustments to the structure of the production process and the correction of existing outdated software complexes, which currently use founders in the manufacture of metal products. Focusing on the best foreign information technologies, identifying their advantages and disadvantages, the principles and methods by which they operate, it becomes possible to create a qualitative technology for the founders, highlighting the main stages of working with the melt and its subsequent processing. The development of software requires a detailed analysis of not only existing advanced technologies, but also needs of the customer, the observance of all stages of the technological process, the definition of the profile of production, its specialization.

The aim of this work is to perform an overview of existing software tools for computer modelling of foundry processes, to determine their advantages and disadvantages, to evaluate the possibilities of using these tools at domestic production and to propose the way to constructing a computer technology developed in accordance with the requirements of Ukrainian foundry enterprises and oriented to work with the Ukrainian base of metals and alloys and suitable for implementation.

The importance of computer simulation is based on the accuracy of simulating the process' physics so that important process variables can be identified and controlled. Visualization of the pouring process in a virtual environment allows founders to timely see and eliminate problems associated with fluid flow, hardening and distortion of the part [2].

The casting process modeling will allow predicting the quality and accurate sizes of foundry products before production, which will significantly reduce the process of producing products and help to determine the possibility of defect formation to eliminate it as well as the chemical composition and mechanical properties of casting. 


\section{OVERVIEW OF THE SOFTWARE USED IN THE FOUNDRY INDUSTRY}

Today in the world various software products are used, which are related to metallurgical and foundry processes.

An overview of modern software in the field of molding has shown that today there are many different software products that are used by technologists-founders at the enterprises, but they are not available for a number of parameters for many industries, especially small ones, in particular, they are expensive, need constant updating and maintenance, but do not solve all the problems facing the foundry during the casting process $[3,4]$.

A comparative analysis of the most common computer systems for simulation of physical processes accompanying metallurgical and foundry technologies was done in [5]. Mathematical modeling of metallurgical and foundry processes, analysis of possible variants of their optimization related to the improvement of various technologies, allows reducing costs for preparation for production and manufacturing of castings.

Below we describe shortly the most used software in the world such as MAGMASOFT, ProCAST, LVMFlow / NovaFlow, POLYGON, advantages and disadvantages of these programs, their functionality.

Magmasoft simulates metal filling, crystallization, stress and strain calculation, structure, distribution of perlite and ferrite, and many other useful parameters.

In the base version, the MAGMASOFT standard allows you to simulate molding in sand-clay shapes and into chalk. For simulation of other types of casting it is necessary to purchase additional modules [6]:

- MAGMAlpdc (low pressure casting);

- MAGMAhpdc (high pressure die casting);

- MAGMAdisa (simulation of casting in the form of bezomaty forms for the DISAMATIC line);

- MAGMAiron (cast iron casting).

Flow Science, SantaFe, NewMexico, announced that they have released a new version of FLOW-3D Cast in software for the metal casting industry. FLOW-3D Cast v4.2 offers an advanced What You See Is What You Need (WYSIWYN) interface, process-oriented work space sand a new cooling model.

FLOW-3D Cast v4.2's WYSIWYN design methodology places the most important information at the top level so that users can quickly see and determine what options need to be set.

Following the design principle of WYSIWYN, FLOW-3D Cast v4.2 introduces the first process-oriented work space for high pressure die casting. Users are guided through the distinct stages of a high pressure die casting process - thermal die cycling, filling, solidification and cooling [7].

A large number of publications on various aspects of metal casting processes there appears to be a lack of gap in technology to specifically define process knowledge. Process knowledge is defined as the list of process variables, their collection system, visualization system and analysis to determine the ranges of relevant process variables that are related to the product characteristics for specific castings made in the foundries [8].

Conducted in [9] review shows that AFS Solid 2000 software combines thermal and volumetric calculations to predict shrinkage porosity. ProCAST uses fi- 
nite element technique and has been adopted for micromodeling, stress, distortion, and automatic meshing. It is also applicable for sand, shell, die casting, permanent mold and lost foam processes. Foundries have used its software for improving the methoding and simulating the solidification process for producing radiographic quality castings. MeshCAST foundry software package is used for fully automatic 3-D mesh generation and is very convenient for design purposes. It can handle complex geometries, and generates the mesh at a faster rate. It is an automatic 3-D tetrahedral mesh generator. AutoCAST foundry software package is a knowledgebased system involving large eddy simulation for combining all the three essential tasks, casting design decisions, casting model creation and process simulation. This approach reduces the overhead of importing and exporting data between the systems for each layout iteration, saving time, and eliminates the possibility of making errors during data transfer.

The book [10] contains a broad collection of data on properties and characteristics for aluminum alloy castings, describes the factors that influence these properties, taking into account composition, microstructure, molding, heat treatment and quality assurance. Also presented are the curves of the heating and cooling process. These data are presented in agreed formats, which make it easy to compare different alloys and temperatures. The authors tried to consider all casting technologies that are available for aluminum alloys. The focus of the process is to review the influence of process selection and process variables on the properties and performance of casting.

In [11] a comparative analysis of the most common computer systems for modelling of physical processes accompanying metallurgical and foundry technologies was conducted. Mathematical modeling of metallurgical and foundry processes, analysis of possible variants of their optimization are connected with the improvement of various technologies which allow reducing costs for preparation for the production and manufacturing of castings. It is clear that at present it is impossible to unambiguously propose a computer system that would satisfy both factory technologists and engineer researchers. When choosing a computer system, the founder must take into account his financial capabilities, as well as the amount of tasks that need to be solved using a modern scientific tool.

In [12] advanced casting modelling tools like Procast ${ }^{\mathrm{TM}}$ allow the foundry engineer to quickly bridge the gap between design and manufacturing. Optimization or improved efficiency during the manufacturing cycle leads to substantial time and cost savings. Computer analysis provides the means for verifying design ideas and viewing the effects of "what ifs" at minimal costs by avoiding time-consuming and expensive rework and retooling.

\section{TECHNOLOGICAL PROCESSES OF GETTING CAST PRODUCTS}

Metal casting is a technological process of obtaining various billets and parts. There are different casting methods which differ in their technology of obtaining castings.

The casting is an original design, which leads to the need to create an independent sprue-feeding system (SFS) for each casting, which serves to fill the mold with a metal by optimal speed, which excludes the formation of casting imperfections and nonmetallic inclusions, and compensation of volumetric shrinkage during the hardening of the casting to obtain in it a metal of a given density. SFS must meet the requirements of technological capability in the manufacture of models, molds and 
castings. However, molded parts have a lot in common in the sizes of walls, nodes, and their joints, thus opening up opportunities for typing SFS constructions and generating general methods for their calculations [12].

\section{EXISTING PROBLEMS AND FEASIBLE SOLUTIONS}

The main direction of improvement of any production is the modernization of known and creation of new technological processes in order to reduce the consumption of materials, reduce energy and labor costs, improve working conditions, eliminate or reduce the harmful effects on the environment. All of this ultimately improves the efficiency of production and output [13].

The authors [11] concluded that it is currently impossible to unequivocally propose a computer system that would satisfy both factory engineers and engineer researchers. Consequently, when choosing a computer system, the founder must take into account the scope of tasks and production, the future use of products, which will result in the selection of the technological process of obtaining the workpiece or finished component, the type of metal or alloy and its financial capabilities. The survey showed that there is a need to develop a software product that would allow the following tasks to be performed:

1) calculation of the filling speed of the form;

2) calculation of hardening;

3) calculation of voltage;

4) thermal voltage;

5) the possibility of automatic computing;

6) analysis of defects;

7) analysis of the type of casting;

8) determination of cooling modes;

9) displaying the image of the process of pouring and freezing on the screenvisualization of the entire technological process, from the injection of molten metal to the form and before its solidification;

10) creating SFS for specific production;

11) analysis of casting of alloys.

In order to increase the competitiveness of graphitized steels with respect to such machine building materials as high-strength pig-iron, bronze, low-alloy steel, it is promising to create a new technology that provides the crystallization of hypereutectoid steel with the formation of spheroidal graphite inclusions and eliminating the formation of structural free cementite. This can be achieved by developing a highly effective modification application in the pre-crystallization period in combination with the optimization of the chemical composition and the rate of cooling of the castings.

As a result of the studies carried out in [14], a highly effective modification process was developed, the main technological parameters for obtaining hypereutectic alloy of steel with spheroidal graphite were determined. The obtained scientific results open the perspective of the development of highly effective technologies and creation of new brands of graphitized steel.

In foundries casting, defect analysis is one of the common applications of expert system. In modern foundries expert systems are mainly used for casting defect analysis. Expert systems are computer programs in which the knowledge and experience of one or more experts is captured and stored to make it widely available. 
The knowledge in an expert system may originate from many sources such as textbooks, reports, databases, case studies, empirical data and personal experience. These systems can be of great assistance in the decision-making process as the computer can be made to think, reason, make inferences and give judgment, conclusions, and solutions to problems [9].

The emergence of software tools at the Ukrainian foundries not only simplifies the process of obtaining the casting, but also increases the volume and speed of production, will reduce the appearance of defects by improving the physical and chemical properties in the casting products.

Taking into account the direction of foundry factories, it becomes possible to create a software tool with auxiliary modules that will be oriented towards the type of casting and industry, the type of metal or alloy, the methods of obtaining casting, the analysis of the assessment of temperature impact on the material and characteristics of its physical properties.

\section{SAND CASTING TECHNOLOGY}

The process of casting in sand forms is the process by which molten metal is poured into a sandy form. Sandblasting is a relatively cost-effective process with fast settings, ideally suited for prototyping or small production cycles. It can be used to produce components of almost any size and shape, from the simplest to the most complex. The precision of the sizes is good and the excellent surface texture can be achieved with the correct finish. Sand can also be recycled, providing both environmental and economic benefits.

Other characteristics of the form (volumetric, shell, refractory, etc.): composition and properties of molding mixtures, methods of their consolidation or hardening, characteristics of castings and alloys for their manufacture, scale of production, etc. determined only as variants of this process and types of equipment for performing specific operations [15].

The paper [16] considers the methods of casting, from which we have selected those that are oriented on the technology of casting in sand forms. Sand casting is the most common method of metal casting, accounting for approximately 75 percent of all metal cast. It consists of forming a cavity in sand with a pattern, filling the cavity with molten metal, allowing it to cool and solidify and then releasing the casting by breaking away the sand [17]. Shell-mold casting is a variation of sand casting in which sand containing a resin binder is cured by heat. Lost-foam casting is a technique similar to investment casting in that it uses an expendable pattern, one made of polystyrene foam rather than wax. The pattern is coated with a refractory material and then encased with sand, forming a one-piece sand mold.

\section{CONSTRUCTING A SPECIALIZED COMPUTER TECHNOLOGY IN FOUNDRY PRODUCTION}

A computer support system for casting solutions is being developed. With its help, the specialist would have the opportunity to get recommendations on what impurities and in what proportions should be added to the initial raw materials and on the choice of a suitable cooling mode to achieve a certain quality of casting. Equally important is the displaying some images on the screen: visualization of the cooling curves of the cast- 
ing (experimental data) and the content of raw materials by its chemical composition in the form of a diagram (mass fraction). The software is aimed at optimizing workflow support and casting process automation. General scheme of the main units and their relationships with the computer system is demonstrated (Fig. 1).

The system will consist of the three main blocks:

1. Database

2. Recommending subsystem (before production and in the process of manufacturing at a specific installation);

3. Analytical subsystem.

The recommending subsystem is linked to both the database and the analytical subsystem. The database contains standards, requirements, experimental data, and recommendations based on analytics on cooling process management.

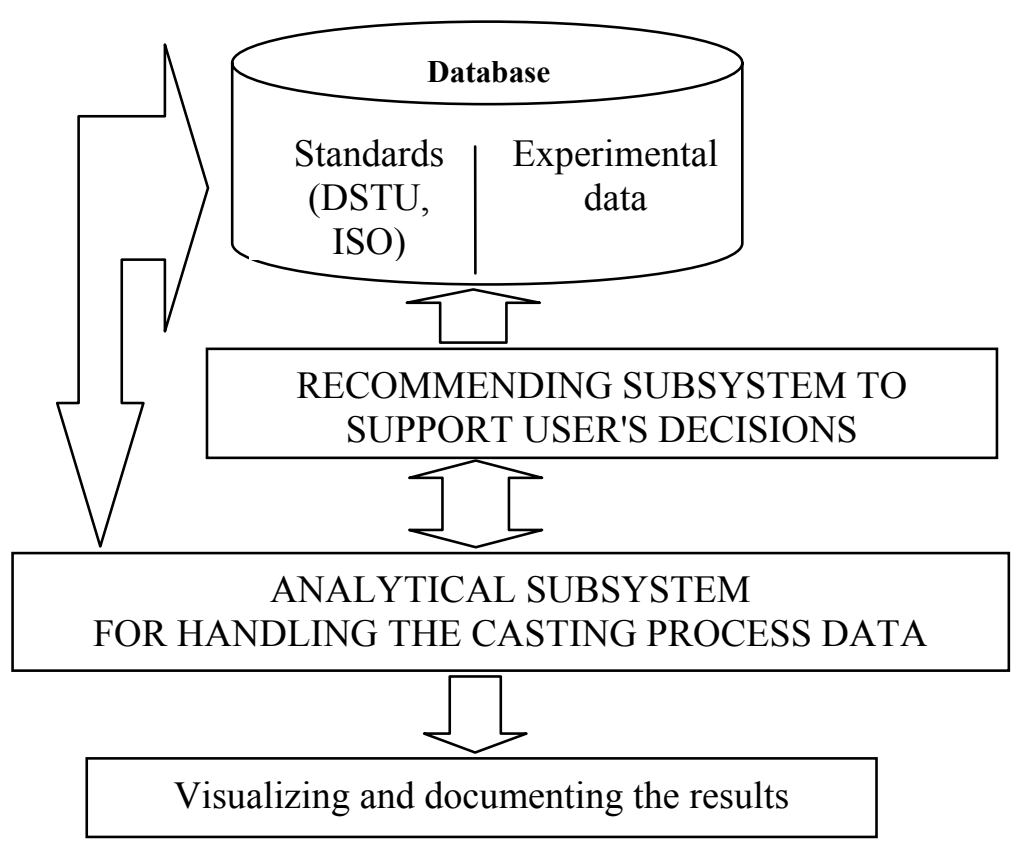

Fig. 1. Flowchart of the foundry support system 


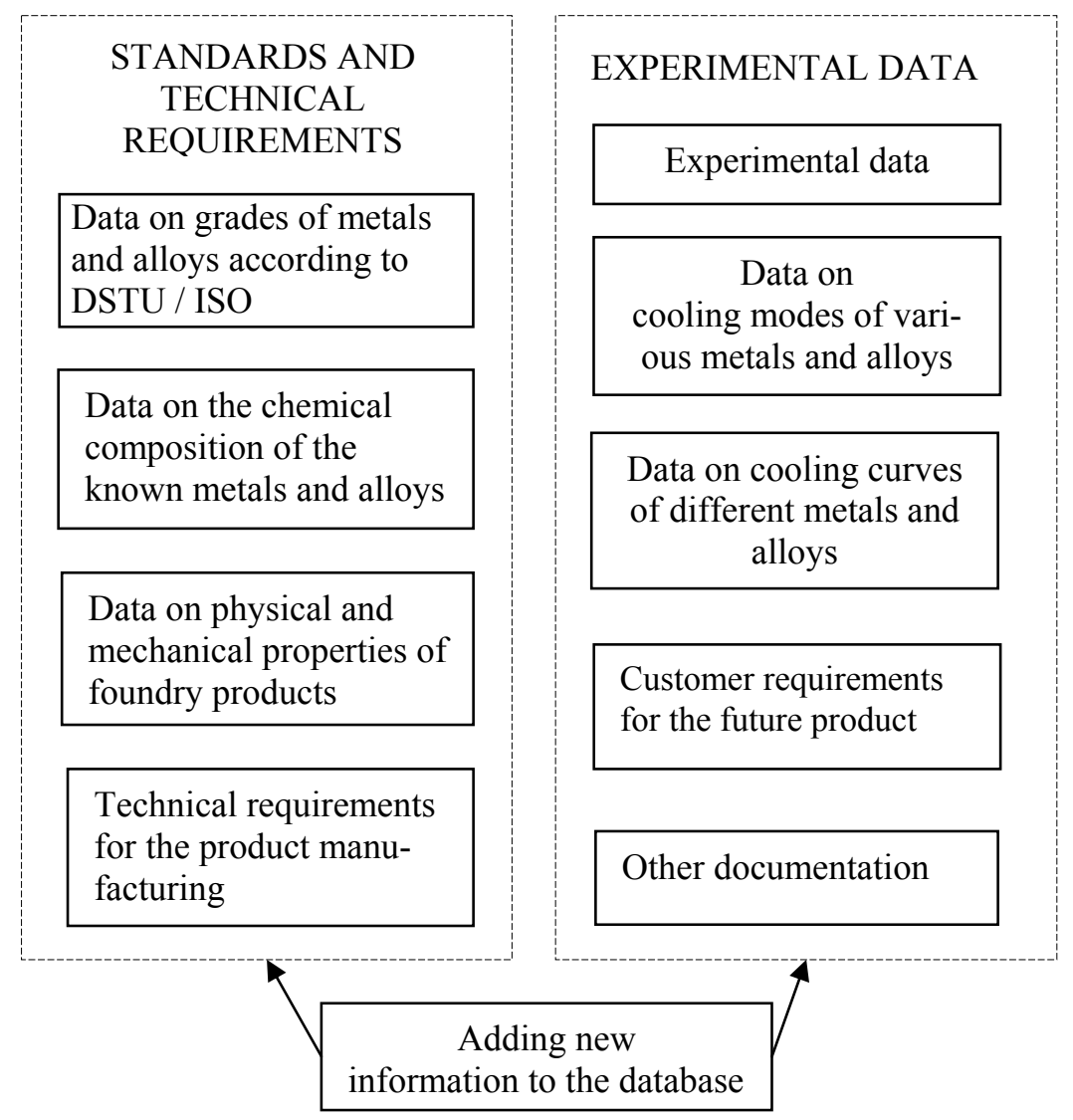

Fig. 2. Block diagram of the database

The block diagram of the database is shown (Fig. 2).

The database consists of two main blocks. The first one contains standards and technical requirements. This data is independent of the installation on which the casting will be processed, it is invariant for all installations.

The second block contains the information of the casting user, which depends on the existing installations and conditions in which the process of casting and measuring the cooling temperature of the alloys takes place, as well as data on all the products that were manufactured and all other documentation required in the operating the casting machine at a specific installation. If necessary, this unit can be adapted for use on another installation with updating all the necessary information.

The user has the opportunity to supplement the database with new information both in the block of standards and specifications and in the block of data.

A flow chart of a recommending subsystem for supporting casting solutions which also consists of two separate blocks is presented (Fig. 3).

This subsystem can be used at the beginning of the casting (reference block) to determine what products can be made from the available raw materials if their chemical composition is known, to select from the database information about the selection of certain additional components of raw materials (its chemical composition) to obtain products of a given quality, and also to select from the experimental 
data of the user information about various alloys that were already made according to the technical requirements of the customer.

In the second block of the subsystem, for example, some types of recommendations are presented based on the results of the experiments performed and models constructed. This unit addresses the analytical subsystem and is intended to provide ongoing guidance to the caster during the casting process.

The analytical subsystem is intended for solving various computational tasks necessary for active support of the foundry maker's decisions. As for now, the following three tasks are implemented in this subsystem:

- construction of models of dependence of the intermediate temperature of casting on the mode of its cooling;

- construction of models of dependence of mechanical properties of a product on the chemical composition of raw materials;

- comparison of the curve of the unknown alloy curve with the standard curves of standard alloys introduced into the database.

The construction of models of temperature dependence on cooling modes makes it possible to use the simulation results to select a suitable cooling mode. This can be done by calculations of the intermediate temperature in different modes [18].

The construction of models of dependence of the mechanical properties of casting on the chemical composition of raw materials makes it possible to adjust the chemical composition of raw materials to obtain certain products. It also helps to evaluate how the increase or decrease of each of the components of the raw material affects the mechanical properties of the finished casting [19].

$$
\begin{aligned}
& \text { 1. The choice of grades of } \\
& \text { metals and alloys that can be } \\
& \text { made from a given raw } \\
& \text { materials }
\end{aligned}
$$

2. Selection of impurities to the available raw material to obtain quality products (with specified properties)

3. Information on the characteristics of the manufactured products and the respective operating modes of the foundry

\section{Recommendations based on the available database}

1. Choosing the right cooling mode to achieve a specific product quality

2 . Determination of alloy quality by comparing its cooling curve with reference curves

3. The choice of the chemical composition of raw materials for the manufacture of products with specified physical and mechanical properties

\section{Recommendations based on the results of experiments and simulations}

Fig. 3. Flow chart of the recommending subsystem 


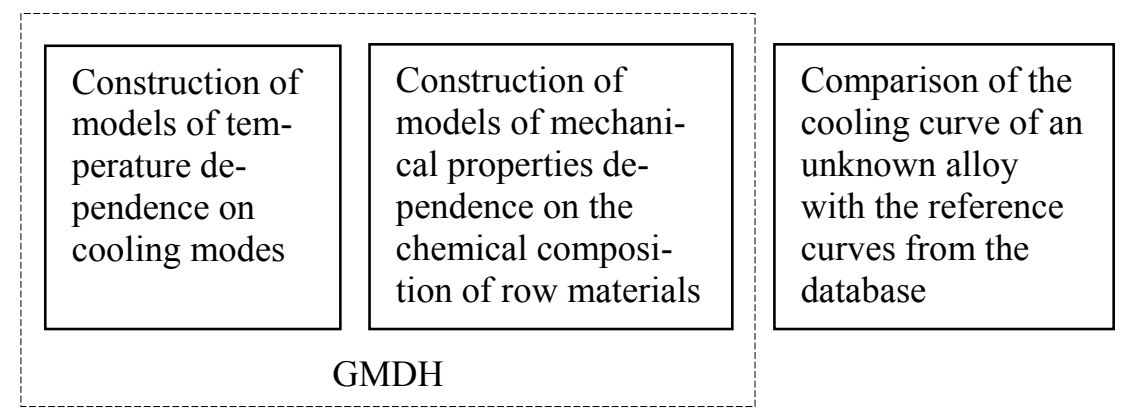

Fig. 4 Scheme of the analytical subsystem (an example)

The third problem which can be solved with the help of the analytical subsystem is to compare the proximity of a curve of an unknown alloy with the reference curves entered in the database, which allows determining its chemical composition.

The block diagram above presents a computer support system for the foundry and its main subsystems. Individual modules are developed using the VBA MS Excel language. This software package can be used on any Windows PC with MS Office installed. Given that the process monitoring data is in Excel or easily imported, such a product will be easy to use and will not require a special training.

The proposed technology substantially develops, supplements and clarifies the general principles of designing the computer technology for modeling the thermal processes of foundry production described in [20].

\section{CONCLUSIONS}

On the basis of the overview of processes and methods of casting with the main attention to the detailed consideration of the methods of casting in the sandy form, we can draw the following conclusions.

The advantages of the molding method in sand forms are: the possibility of manufacturing castings of high weight and of complex forms; ability to automate production; castings are made from cast alloys, besides refractory that allows using scrap in remelting; cheap cost of receiving castings.

The disadvantages include the following: roughness of the surface which requires further treatment of castings and leads to a large amount of waste; the probability of defects occurrence is of greater extent than in other methods of casting; bad sanitary conditions of production.

Although sand casting technology has certain disadvantages, it still remains one of the most widely used casting technologies in the world due to the possibility of creating any shape of various sizes at a low price.

Therefore the creating computer technologies that will take into account all the peculiarities and help to enhance the casting quality is obviously of great importance. The paper presents the design features of a technology oriented to support casting solutions in the process of casting cooling. It is designed to automate some stages of the casting process as well as help specialists to make the casting process more manageable and replace costly experiments with their modeling to evaluate the influence of various factors on the casting during the cooling process. 
The general scheme of technology for support of decisions of the foundry and its main subsystems - recommending and analytical, as well as the structural scheme of the database as a necessary component of the developed technology are presented.

\section{REFERENCES}

1. Mehta N.D., Gohil A.V., Sachindra, Doshi J. Innovative Support System for Casting Defect Analysis - A Need of Time. Materials Today: Proceedings. Vol. 5. Issue 2. Part 1. 2018. P. 4156-4161.

2. Gumann M., Sholapurwalla A. Investment Casting Simulation. URL: https://www.esiroup.com/sites/default/files/resource/publication/1704/t_investmentcasting.pdf. (Last accessed: 06.05.2017).

3. Kravchenko O.V., Savchenko E.A. Information technology of inductive modeling of casting process monitoring. Inductive modeling of complex systems. Kyiv: IRTC ITS. 7. 2015. P. 140-146 (In Ukranian)

4. Tokova O.V., Savchenko E.A. Approach to the development of information support solutions for foundry production. Inductive modeling of complex systems. Kyiv : IRTC ITS. 8. 2016. P. 194-202 (In Ukranian)

5. Zhiganov N.K., Fomina E.E. Program for modeling the process of continuous casting of nonferrous metals and their alloys. Software products and systems. 2008. No. 1. P. 10-12.

6. URL: https://www.magmasoft.de/en/ (Last accessed: 02.10.2019).

7. URL: http://www.afsinc.org/news/AFSNewsList.cfm?Yr=2016 (Last accessed: 13.04.2016).

8. Roshan H. Process knowledge in foundries.URL: https://cdn2.hubspot.net/hubfs/ 237924/Processknowledge-DrRoshan-Jan31-2012.pdf (Last accessed: 12.11.2018.)

9. Thoguluva R.V., Piccardo P. Computers in Foundries. Metallurgical Science and Technology. Vol. 30-2 Ed. 2012. P. 28-38.

10. Kaufman J.G., Rooy E.L. Aluminum Alloy Castings: Properties, Processes and Applications. ASM International. 2004. 340 p.

11. Tarasevich N.I., Korniec I.V., Tarasevich I.N., Dudchenko A.V. Comparative analysis of computer simulation systems for metallurgical and casting processes. Metal and casting of Ukraine. No. 5. 2010. P. 20-25.

12. Matthias Gäumann, Adi Sholapurwalla Investment casting simulation URL: https://pdfs.semanticscholar.org/73e4/a68d4ad01a8c76bda9489da69e97508402ec.pdf (Last accessed: 12.11.2018.)

13. Anton V.A., Balaykin A.V., Smelov VG., Agapovichev A.V. Application of Additive Technologies in the Production of Aircraft Engine Parts. Modern Applied Science. Vol. 9. No. 4. 2015. P. 151-159.

14. Dudchenko A.V. Evolutionary development of computer modeling systems for foundry processes at "NMBP". Compliance with the requirements of the time. (Kramatorsk, $30^{\text {th }}$ of Sept $-4^{\text {th }}$ of Oct. 2013). Kramatorsk, on «NMBP», 2013. P. 97-98. (In Russian).

15. URL: http://uas.su/books/spesialmethodsforcasting/1/razdel1.php. (Last accessed: 01.11.2018.)

16. Treyger, P.E. Overview of Foundry Processes and Technologies: Manufacturing Metal Castings. URL: https://www.cedengineering.com/userfiles/Castings.pdf. (Last accessed: 01.11.2018.)

17. Tokova O., Savchenko Ye. Inductive Modelling as a Basis of Informational Support of Decisions in Casting Production. Proceedings of the XII IEEE International Conference CSIT-2017 \& International Workshop on Inductive Modeling (Lviv, $5^{\text {th }}-8^{\text {th }}$ of Sept., 2017). Lviv, 2017. P. 507-510.

18. Savchenko, Ye.A., Kravchenko, O.V. Application of the inductive approach for simulation of the cooling process of casting according to experimental data. Inductive modeling of complex systems. Collected research papers. Issue 6. Kyiv: IRTC ITS NASU. 2014. P. 126-136. (In Ukranian)

19. Savchenko, Ye.A., Stepashko V.S., Tokova O.V. The construction task for a decision support system in foundry industry. Proceedings of XXIV International Conference of Automatica-2017. (Kyiv, $13^{\text {th }}-15^{\text {th }}$ of Sept. 2017). Kyiv, 2017. 196 p. (In Ukranian)

20. Tokova O.V. The task of the computer technology construction for thermal processes modeling of foundry production. Upr. sist. mas. 2018. 4 (276). P. 84-95. (In Ukranian)

Received 22.10.2019 


\section{ЛІТЕРАТУРА}

1. Mehta N.D., Gohil A.V., Sachindra, Doshi J. Innovative Support System for Casting Defect Analysis - A Need of Time. Materials Today: Proceedings. Vol. 5. Issue 2. Part 1. 2018. P. 4156-4161.

2. Gumann M., Sholapurwalla A. Investment Casting Simulation. URL: https://www.esiroup.com/sites/default/files/resource/publication/1704/t_investmentcasting.pdf. (Дата звернення: 06.05.2017.)

3. Кравченко О.В., Савченко Є.А. Розробка інформаційної технології моніторингу процесів ливарного виробництва. Індуктивне моделювання складних систем. 3бірник наукових праиь. Київ: МННЦ ІТС. Вип.7. 2015. С. 140-146.

4. Токова О.В., Савченко Є.А. Підхід до розроблення системи інформаційної підтримки рішень у ливарному виробництві. Індуктивне моделювання складних систем. Київ: МННЦ ІТС. 8. 2016. С. 194-202.

5. Zhiganov N.K., Fomina E.E. Program for modeling the process of continuous casting of nonferrous metals and their alloys. Software products and systems. 2008. No. 1. P. 10-12.

6. URL: https://www.magmasoft.de/en/ (Дата звернення: 02.10.2019.).

7. URL: http://www.afsinc.org/news/AFSNewsList.cfm?Yr=2016 (Дата звернення: 13.04.2016 .).

8. Roshan J. Process knowledge in foundries. URL: http://www.afsinc.org/ files/MC/stories/issuearchive/Processknowledge-DrRoshan-Jan 31-2012.pdf, 2012. (Дата звернення: 12.11.2018.)

9. Thoguluva R.V., Piccardo P. Computers in Foundries. Metallurgical Science and Technology. Vol. 30-2 - Ed. 2012. P. 28-38.

10. Kaufman J.G., Rooy E.L. Aluminum Alloy Castings: Properties, Processes and Applications. ASM International. 2004. 340p.

11. Тарасевич Н.І., Корниец I. В., Тарасевич І.Н., Дудченко А.В. Сравнительный анализ систем компьютерного моделирования металлургических и литейных процессов. Металл и литье Украиныл. 2010. № 5. С. 20-25.

12. Matthias Gäumann, Adi Sholapurwalla Investment casting simulation URL: https://pdfs.semanticscholar.org/73e4/a68d4ad01a8c76bda9489da69e97508402ec.pdf. (Дата звернення: 12.11.2018.)

13. Anton V.A., Balaykin A.V., Smelov VG., Agapovichev A.V. Application of Additive Technologies in the Production of Aircraft Engine Parts. Modern Applied Science. Vol. 9. No. 4. 2015. P. 151-159.

14. Дудченко А. В. Определение технологических пределов применимости литниковых систем различных конструкций для условий скоростной заливки. Материалы IV Международной научно-технической конференции «Перспективные технологии, материалы и оборудование в литейном производстве». (Краматорск, 30 сентября - 4 октября 2013). г. Краматорск, 2013. С.97-98.

15. URL: http://uas.su/books/spesialmethodsforcasting/1/razdel1.php. (Дата звернення: 01.11.2018.)

16. Treyger, P.E. Overview of Foundry Processes and Technologies: Manufacturing Metal Castings. URL: https://www.cedengineering.com/userfiles/Castings.pdf. (Дата звернення: 01.11.2018.)

17. Tokova O., Savchenko Ye. Inductive Modelling as a Basis of Informational Support of Decisions in Casting Production. Proceedings of the XII IEEE International Conference CSIT-2017 \& International Workshop on Inductive Modeling (Lviv, $5^{\text {th }}-8^{\text {th }}$ of Sept. 2017). Lviv, 2017. P. 507-510.

18. Савченко Є.А., Кравченко О.В. Застосування індуктивного підходу для моделювання процесу охолодження виливка за експериментальними даними. Індуктивне моделювання складних систем. Київ: МННЦ ІТС. Вип. 6. 2014. С. 126-136.

19. Савченко Є.А., Степашко В.С., Токова О.В. Задача конструювання системи підтримки прийняття рішень у ливарному виробництві. Зб. тез доповідей XXIV Міжнародної конференції з автоматичного управління Автоматика-2017. (Київ, 13-15 вересня, 2017). Київ, 2017. С. 196. 
20. Токова О.В. Задача розроблення комп’ютерної технології моделювання термічних процесів ливарного виробництва. Управляющие системы и машины. 2018. № 4. C. $84-95$.

Отримано: 22.10.2019

Токова O.В.,

молодш. наук. співроб. відд. інформаційних

технологій індуктивного моделювання,

e-mail: len327@ukr.net

Савченко Є.А., канд. техн. наук, старш. наук. співроб.,

старш. наук. співроб. відд. інформаційних

технологій індуктивного моделювання,

e-mail: savchenko_e@meta.ua

Степашко В.С., д-р техн. наук, професор

зав. відд. інформаційних технологій

індуктивного моделювання,

e-mail: stepashko@irtc.org.ua

Міжнародний науково-навчальний центр інформаційних технологій

та систем НАН України та МОН України,

пр. Акад. Глушкова, 40, м. Київ, 03187, Україна

\section{КОНСТРУЮВАННЯ КОМП’ЮТЕРНОЇ ТЕХНОЛОГІЇ ІНФОРМАЦІЙНОЇ ПІДТРИМКИ РІШЕНЬ У ПРОЦЕСІ ЛИВАРНОГО ВИРОБНИЦТВА}

Вступ. Для забезпечення якісного виготовлення ливарних виробів необхідні передові комп'ютерні технології, які містили б не лише базу даних металів та сплавів, а й інформацію про процеси утворення дефектів, способи отримання виливків заданої якості, умови та чинники, які впливають на структуру лиття під час термічного оброблення.

Використання інформаційних технологій на українських ливарних підприємствах означає внесення змін у структуру виробничого процесу та виправлення наявних застарілих програмних комплексів, які наразі використовують засновники у виробництві металевих виробів. Зосереджуючись на кращих зарубіжних інформаційних технологіях, виявляючи їхні переваги та недоліки, принципи та методи, якими вони керуються, стає можливим створити для замовників якісну технологію, виділивши основні етапи роботи з розплавом та подальшого його перероблення. Розроблення програмного забезпечення вимагає детального аналізу не тільки наявних передових технологій, а й потреб замовника, дотримання всіх етапів технологічного процесу, визначення профілю виробництва, його спеціалізації.

Метою дослідження $\epsilon$ аналіз сучасних підходів та засобів, що використовуються в галузі підтримки рішень ливарника з метою розроблення такої комп'ютерної технології, яка буде містити базу даних українських стандартів та технічних вимог і надаватиме змогу отримувати рекомендації щодо завдань, які виникають у процесі лиття.

Результати. Проведено аналіз сучасного програмного забезпечення для комп'ютерного моделювання процесів в галузі формування металів і методів, що лежать в основі програмних продуктів. Результати аналізу використано у створенні комп'ютерної технології моделювання теплових процесів у галузі ливарного виробництва, орієнтовану на умови промисловості України, що надасть змогу спростити процес отримання литва, внаслідок чого можна буде збільшити обсяг виробництва та зменшити появу дефектів ливарних виробів у технологічному процесі, що підвищить їхню конкурентоспроможність. Наведено блок-схему комп'ютерної технології інформаційної підтримки прийняття рішень у процесі ливарного виробництва. Описано основні блоки цієї системи і завдання, які вони будуть виконувати.

Ключові слова: лиття, ливарне виробництво, виливок, комп'ютерна технологія, інформаційна підтримка керувальних рішень, метод групового урахування аргументів (МГУА). 


\section{Токовая Е.B,}

младш. науч. сотр. отд. информационных технологий

индуктивного моделирования,

e-mail: len327@ukr.net

Савченко E.A., канд. техн. наук, старш. науч. сотр.,

старш. науч. сотр. отд. информационных технологий

индуктивного моделирования,

e-mail: savchenko_e@meta.ua

Степашко В.С., д-р техн. наук, профессор,

зав. отд. информационных технологий

индуктивного моделирования,

e-mail: stepashko@irtc.org.ua

Международный научно-учебный центр информационных технологий и систем НАН Украины и МОН Украины, пр. Акад. Глушкова, 40, г. Киев, 03187, Украина

\section{КОНСТРУИРОВАНИЕ КОМПЬЮТЕРНОЙ ТЕХНОЛОГИИ ИНФОРМАЦИОННОЙ ПОДДЕРЖКИ РЕШЕНИЙ В ПРОЦЕССЕ ЛИТЕЙНОГО ПРОИЗВОДСТВА}

Проведен анализ современного программного обеспечения для компьютерного моделирования процессов в области формирования металлов и сплавов. Результаты анализа планируется использовать при создании компьютерной технологии моделирования тепловых процессов в области литейного производства, которая будет ориентирована на промышленные условия Украины и позволит упростить процесс получения литья, в результате чего увеличится объем производства, уменьшится появление дефектов изделий в технологическом процессе, чтобы сделать их более конкурентоспособными.

Приведена блок-схема компьютерной технологии информационной поддержки принятия решений в процессе литейного производства. Описаны основные блоки этой системы и задачи, которые они будут решать.

Ключевые слова: литье, литейное производство, отливка, компьютерная технология, информачионная поддержка управленческих решений, метод группового учета аргументов (МГУА) 